\title{
SSPWM THREE PHASE INVERTER DESIGN AND EXPERIMENTED ON UNBALANCED LOADS
}

\author{
Erol Can, H. Hüseyin Sayan
}

Original scientific paper A circuit-oriented approach for the analysis of pulse width modulation (PWM) three phase inverter is presented in order to run unbalanced loads in low nonlinear effects as harmonics. This method uses the identification of a six switch nonlinear device, which consists of only the active and passive switches in three phase inverter. When operating characteristics of the MOSFET switch are determined according to step-sinus pulse width modulation method, an average equivalent inverter model can be formed. After that, SSPWM technique is used to drive unbalanced loads in order to compare with common pulse width modulation (PWM) running unstable loads. First, the inverter load of resistive $(R)$ and inductive $(L)$ are performed at the MATLAB Simulink so that by PWM technique could be shown the reducing effect of the harmonic on loads. After that, the system is implemented by real elements as MOSFETs, PIC17F877A, PC 817 phototransitors.

Keywords: harmonic; step sinus pulse-width modulation; the inverter; unbalanced loads

Konstrukcija SSPWM trofaznog izmjenjivača i primjena kod nestabilnih potrošača

Izvorni znanstveni članak

Daje se prikaz pristupa usmjerenog strujnom krugu za analizu modulacije širine impulsa (pulse width modulation - PWM) za trofazni izmjenjivač kod neuravnoteženih potrošača sa slabim nelinearnim učincima kao harmonike. U toj se metodi primjenjuje identifikacija nelinearnog uređaja sa šest prekidača, a sastoji se samo od aktivnih i pasivnih prekidača u trofaznom izmjenjivaču. Nakon što su se odredile radne karakteristike MOSFET prekidača u skladu s metodom modulacije širine step-sinus impulsa, može se formirati prosječni ekvivalentni model izmjenjivača. Nakon toga, primjenom SSPWM tehnike pogone se nestabilni potrošači kako bi se usporedili s nestabilnim potrošačima s uobičajenom modulacijom širine impulsa. Najprije se na MATLAB Simulink primjenjuju rezistivna $(R)$ i induktivna $(L)$ opterećenja izmjenjivača kako bi se primjenom PWM tehnike pokazao reducirajući učinak harmonika na potrošače. Nakon toga, sustav se implementira realnim elementima kao što su MOSFET, PIC17F877A, PC 817 foto transitori.

Ključne riječi: harmonike; izmjenjivač; nestabilni potrošači; step-sinus modulacija širine impulsa

\section{Introduction}

Solar sources and some direct current $(\mathrm{dc})$ sources have to be converted to alternating current (ac) sources so that induction motors and some ac loads can be driven [1]. Therefore, power electronic circuits were used in scientist articles [2, 3]. The applications of inverter and converter in Power electronic circuit are crucial for the conversion of direct current electrical energy [1] and [2]. Therefore, power electronic circuits are used as PWM inverter. However, the implementation of some PWM techniques for the three-phase induction machine and unbalanced resistive $(R)$ and inductive $(L)$ loads drivers cause some restrictions and complexity [8]. Three-phase inverters with pulse-width modulation (PWM) can generate a waveform comprised of a fundamental and harmonics because inverters have nonlinear switches as MOSFETs (see [3, 4, 5]). Some papers are presented so that harmonic can be reduced on PWM inverters running loads [6, 7]. Once operating characteristics of the MOSFET switch are determined according to step sinus modulation developed for unbalanced loads, mathematical equation is created for total alternating voltage of load. New mathematical model is calculated according to step sinus pulse width modulation (SSPWM) with unbalanced loads unlike other studies (see [10, 11, 12]). PWM duty cycle can be controlled with the new modulation technique for example as shown in Fig. 2a. New mathematical model with SSPWM inverter according to step sinus pulse width modulation is simulated for unbalanced loads, results of proposed PWM inverter are compared with common PWM controlling inverter. According to results of simulations, loads currents of proposed inverter have low harmonic distortions while load currents of common PWM inverter have high harmonic distortions. In the experimentation, MOSFETs, PIC17F877A, PC 817 photo transistors are used to construct the three phase inverter. Alternating currents can be created as sinus shape when SSPWM controls unbalanced $R$ and $L$ loads. But, alternating currents cannot be created as sinus shape when common PWM controls unbalanced $R$ and $L$ loads. DC voltage input implemented inverter running loads have low high performance although Microchip 16F877A and MOSFET are used for inverter circuits. In addition, high variable frequency voltage and low total harmonic distortion are produced in low cost. Implementations of different mathematical model and new modulation technique for inverter are succeeded in the article by demanded results.

\section{Design of SSPWM inverter with new modulation technique}

Three-phase voltage PWM DC/AC inverter system is given in Fig. 1. Assuming the resistance of the output reactor and the internal resistance of the system are seen as $R_{1}, R_{2}$ and $R_{3} . L_{1}, L_{2}$ and $L_{3}$ are the reactors. $i_{a}, i_{b}$ and $i_{c}$ are the phase current of the inverter output. $V_{d c}$ is the DC voltage, DC current provided by the DC voltage source S1-S6 for the MOSFET switches. Three phase inverter circuit model is constructed for SSPWM method providing new mathematical model although inverter circuit is a common topology model shown in Fig. 1. 


\subsection{Step-sinus pulse width modulation (SSPWM) as single value increasing duty cycle}

Pulse width modulation technique is used widely in study for motors running and different loads. The paper presents new modulation technique. The new pulse width modulation technique is the step-sinus pulse width modulation (SSPWM) technique shown in Fig. 2. SSPWM is formed when two different triangles are compared with three step sinus signals. Sinus signal has steps that increase $b$ unit lengths on vertical and different $\mathrm{k}$ unit lengths on horizontal as shown in Fig. 2(a). Interactions of steps with triangles form similar triangles. Every formed triangle has different size in all formed triangles. Pulse width is produced with similar triangles rules on half period (T/2). Pulse widths are shown in Fig.2 (b) as similar triangles. $D_{f}$ is first pulse width, $D_{a}$ is average pulse width, $n$ is sampling number.

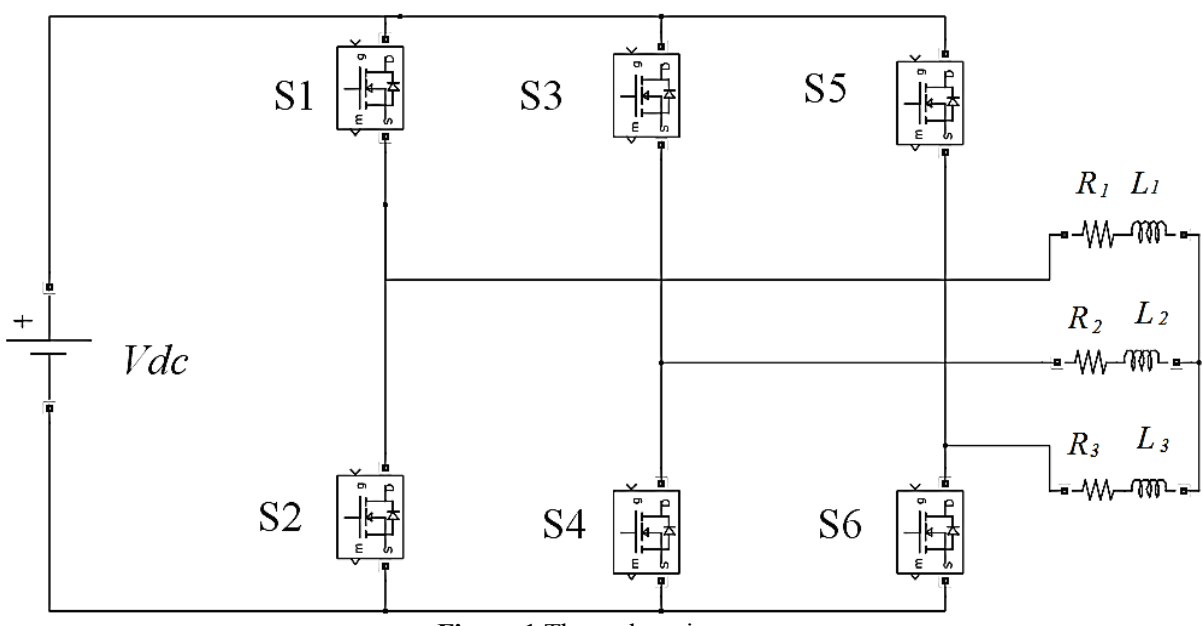

Figure 1 Three phase inverter

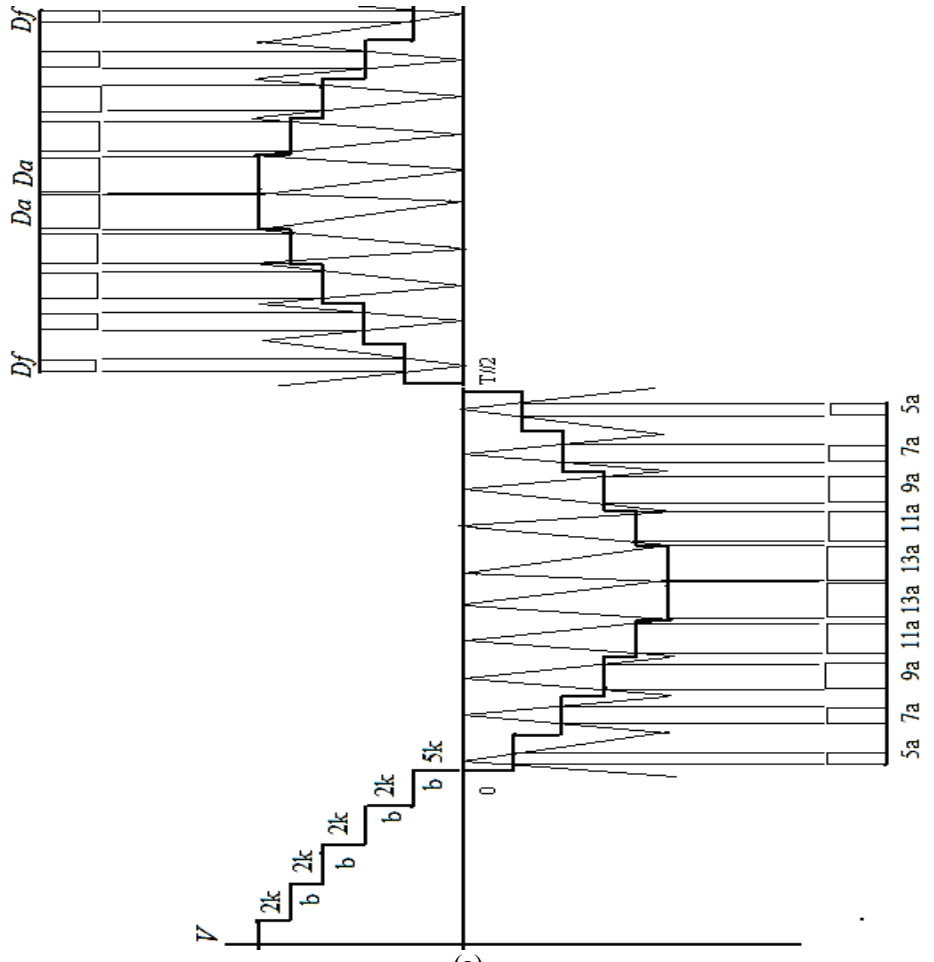

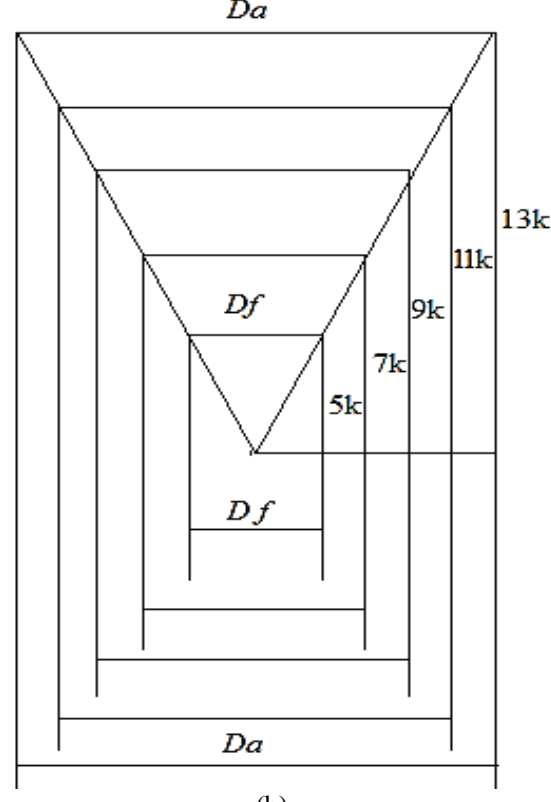

(b)

SSPWM producing current shape and current equation are given in Fig. 3.

a)

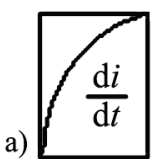

b)

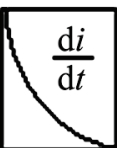

Figure 3 a) PWM producing current in between $T / 2$ and $T$; b) PWM producing current in between 0 and $T / 2$

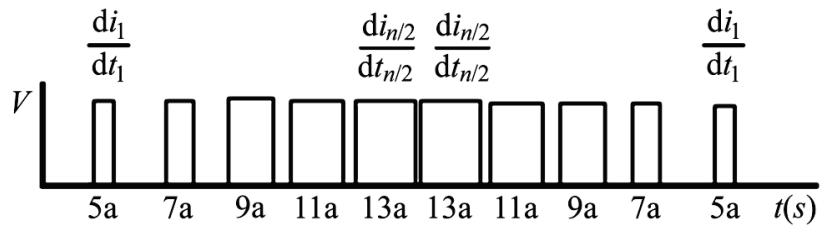

Figure 4 Linear increases of the PWM signals are created at comparison of the results 
The size changes of the SSPWMs are 5a, 7a, 9a, 11a, $13 \mathrm{a}$ in period of $T / 2$ as shown in Fig. 4.

Step sinus pulse width modulation produces total current of equation as in Eq. (1).

$$
\frac{\mathrm{d} i}{\mathrm{~d} t}=2\left(\frac{\mathrm{d} i_{1}}{\mathrm{~d} t_{1}}+\frac{\mathrm{d} i_{2}}{\mathrm{~d} t_{2}}+\cdots+\frac{\mathrm{d} i_{n / 2}}{\mathrm{~d} t_{n / 2}}\right) .
$$

Pulse widths produced by step sinus pulse width modulation create total alternating voltage on period of $T / 2$. Pulse widths increase from $D_{f}$ to $D_{a}$. The increases are linear because of similar triangle rules as in Fig. 2. There are $\mathrm{n}$ pulses on period of $T / 2$. So, pulse widths are added as Eq. (2)

$$
\left(\frac{D_{f}+D_{a}}{2}\right) \cdot n \text {. }
$$

If three phases step sinus signals are compared with triangles according to presented new modulation technique at the MATLAB Simulink as shown in Fig. 5, SSPWM are produced for six switches as in Fig. 6.

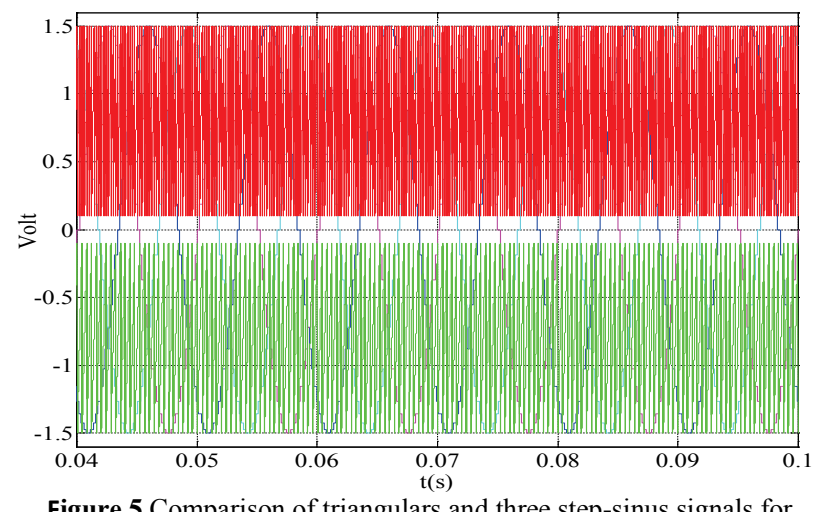

Figure 5 Comparison of triangulars and three step-sinus signals for SSPWM
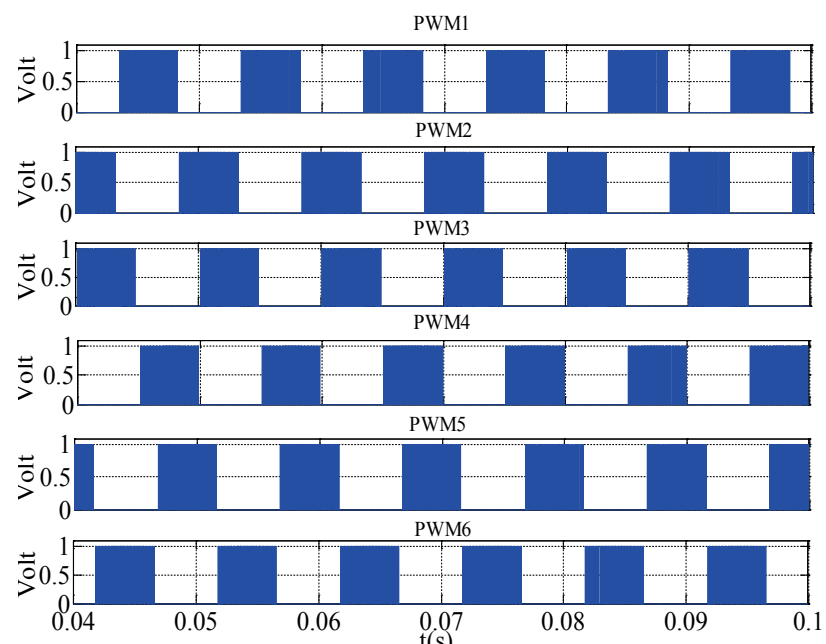

Figure 6 PWM1 for S1, PWM2 for S2, PWM3 for S3, PWM4 for S4, PWM5 for S5, PWM6 for S6.

The Mathematical model of the DC/AC Inverter for Fig. 1 can be created after six PWM are obtained as Fig. 4. $L_{1}=2 L_{2}=L_{3}=L, R=R_{1}=2 R_{2}=R_{3}$ are assuming loads for three-phase $a, b$ and $c$ coordinates. $R$ and $L$ loads are connected as star. Assuming equivalent resistances are $R_{a}$,
$R_{b}$ and $R_{c}$ for line to line. $L_{a}, L_{b}$ and $L_{c}$ are the inductors for line to line. Sources voltage is $V=V_{d c}$. Three-phase inverter circuit has six MOSFETs. These MOSFETs are switched in different groups of three six times in succession. Therefore, a $360^{\circ}$ sinus wave is created with $60^{\circ}$ switching angles of MOSFETs. Phase to phase voltages and line to line voltages are obtained after three phase inverter performed as $360^{\circ}$. Alternating voltage $\left(V_{a c}\right)$ value is calculated by switching pulse widths added as Eq. (2) for period of $T / 2$. After that, mathematical equation is formed for line to line alternating voltage as Eq. (3).

$$
\frac{\left(\frac{D_{f}+D_{a}}{2}\right) \cdot n \cdot V_{d c}}{\frac{T}{2}}=\left(\frac{D_{f}+D_{a}}{T}\right) \cdot n \cdot V_{d c} .
$$

Alternating voltage value is calculated according to switch is OFF as Eq. (4) for period of $T / 2$. After that, mathematical equation is formed for line to line alternating voltage as Eq. (6). $D_{a}$ is $3 a ; D_{f}$ is $a$, step vertical size is $b . V_{d c}$ is direct voltage.

$$
\begin{aligned}
& {[b-a+b-3 a+\cdots+b-(n-1) a]=n b-2 \sum_{a=1}^{n / 2}(2 a-1),} \\
& 2\left[\left(\frac{n}{2} b\right)-\frac{n}{2} \cdot \frac{a+(n-1) a}{2}\right]=n \cdot\left(\frac{2 b-a n}{2}\right), \\
& V_{a c}=V_{d c}-\frac{n \cdot\left(\frac{2 b-a n}{2}\right)}{\frac{\mathrm{T}}{2}} \cdot V_{d c}=V_{d c}-n \cdot\left(\frac{2 b-a n}{T}\right) \cdot V_{d c} .
\end{aligned}
$$

If differential voltage equations $R$ and $L$ loads are used for new mathematical models, Eq. (7) and Eq. (8) are formed. When total switching pulse widths of alternating voltage are calculated according to switching duty cycles with considering values of a, Eq. (7) is formed. When total switching pulse widths of alternating voltage are calculated according to switching values of $b$ and a, Eq. (7) is formed.

$$
\begin{aligned}
& \left(\frac{D_{f}+D_{a}}{T}\right) \cdot n \cdot V_{d c}=\frac{\mathrm{d} i}{\mathrm{~d} t} L+i R=V_{a c} \\
& V_{d c}-n \cdot\left(\frac{2 b-a n}{T}\right) \cdot V_{d c}=\frac{\mathrm{d} i}{\mathrm{~d} t} L+i R=V_{a c}
\end{aligned}
$$

Differential current equations can be calculated as Eq. (9) and Eq. (10).

$$
\begin{aligned}
& \left(\frac{D_{f}+D_{a}}{T L_{a}}\right) \cdot n \cdot V_{d c}-\frac{i R}{L}=\frac{\mathrm{d} i}{\mathrm{~d} t}, \\
& \frac{V_{d c}}{L}-n \cdot\left(\frac{2 b-a n}{T L}\right) \cdot V_{d c}-\frac{i R}{L}=\frac{\mathrm{d} i}{\mathrm{~d} t} .
\end{aligned}
$$

If mathematical equation is formed for $0 \div 60^{\circ}$ switching time, S1-S3-S6 are ON and S2-S4-S5 are OFF. If mathematical equation is formed for $0 \div 120^{\circ}$ switching 
time, S2-S3-S6 are $\mathrm{ON}$ and $\mathrm{S} 1-\mathrm{S} 4-\mathrm{S} 5$ are OFF. Differential equation is formed from current and voltage equations for a phase as Eq. (11).

$$
\frac{V_{d c}}{L_{a}}-n \cdot\left(\frac{2 b-a n}{T L_{a}}\right) \cdot V_{d c}-\frac{i_{a} R_{a}}{L_{a}}=\frac{\mathrm{d} i_{a}}{\mathrm{~d} t} .
$$

If mathematical equation is formed for $60-120^{\circ}$ switching time while $R_{1}$ and $R_{2}$ are $2 R_{3}, L_{1}$ and $L_{2}$ are $2 L_{2}$, $\mathrm{S} 2-\mathrm{S} 3-\mathrm{S} 6$ are ON and S1-S4-S5 are OFF. If mathematical equation is formed for $120 \div 180^{\circ}$ switching time, S2-S3$\mathrm{S} 5$ are $\mathrm{ON}$ and $\mathrm{S} 1-\mathrm{S} 4-\mathrm{S} 6$ are OFF. Differential equation is formed from current and voltage equations for $b$ phase as Eq. (12).

$$
\frac{V_{d c}}{L_{b}}-n \cdot\left(\frac{2 b-a n}{T L_{b}}\right) \cdot V_{d c}-\frac{i_{b} R_{b}}{L_{b}}=\frac{\mathrm{d} i_{b}}{\mathrm{~d} t} .
$$

If mathematical equation is formed for $120-180^{\circ}$ switching time, S1-S4-S5 are ON and S2-S3-S6 are OFF. If mathematical equation is formed for $180-240^{\circ}$ switching time, S1-S4-S6 are ON and S2-S3-S5 are OFF. Differential equation is formed from current and voltage equations for c phase as Eq. (13).

$$
\frac{V_{d c}}{L_{c}}-n \cdot\left(\frac{2 b-a n}{T L_{c}}\right) \cdot V d c-\frac{i_{c} R_{c}}{L_{c}}=\frac{\mathrm{d} i_{c}}{\mathrm{~d} t} .
$$

Matrix form is created from Eq. (11), Eq. (12), and Eq. (13) as Eq. (14)

$$
\begin{aligned}
& {\left[\begin{array}{c}
\mathrm{d} i_{a} \\
\mathrm{~d} t \\
\frac{\mathrm{d} i_{b}}{\mathrm{~d} t} \\
\frac{\mathrm{d} i_{c}}{\mathrm{~d} t}
\end{array}\right]=\left[\begin{array}{ccc}
\frac{-I_{a} R_{a}+V_{d c}}{L_{a}} & 0 & 0 \\
0 & \frac{-I_{b} R_{b}+V_{d c}}{L_{b}} & 0 \\
0 & 0 & \frac{-I_{c} R_{c}+V_{d c}}{L_{c}}
\end{array}\right]-} \\
& -\left[\begin{array}{ccc}
n \cdot\left(\frac{2 b-a n}{T L_{a}}\right) & 0 & 0 \\
0 & n \cdot\left(\frac{2 b-a n}{T L_{b}}\right) & 0 \\
0 & 0 & n \cdot\left(\frac{2 b-a n}{T L_{c}}\right)
\end{array}\right] \cdot\left[\begin{array}{c}
V_{d c} \\
V d c \\
V d c
\end{array}\right] .
\end{aligned}
$$

\section{Experimental results \\ 3.1 Inverter simulation}

Three phase inverter simulation model is shown in Fig. 9. New mathematical model with step sinus pulse width modulation inverter is compared with common PWM controlling inverter. If SSPWM controlling three phase inverter is running unbalanced $R$ and $L$ loads at the MATLAB Simulink, phase currents are created as in Fig. 7. If common PWM controlling three phase inverter is running unbalanced $R$ and $L$ loads at the MATLAB Simulink, phase currents are created as in Fig. 8.

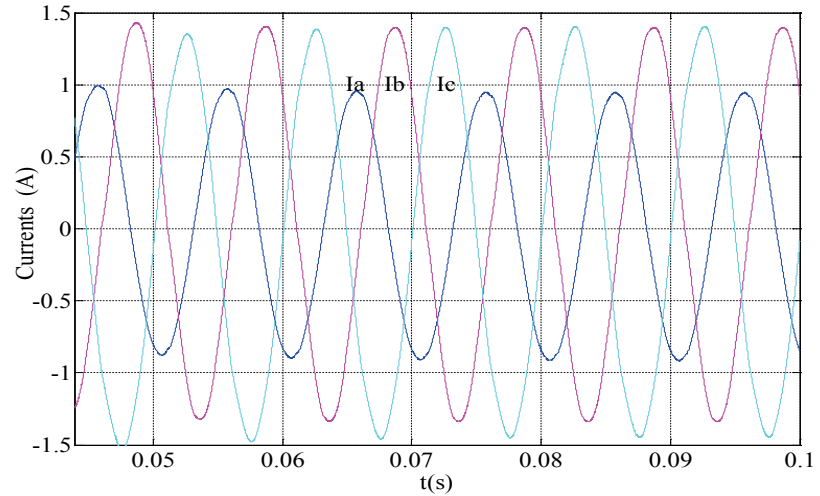

Figure 7 Phase currents of unbalanced $R$ and $L$ loads according to SSPWM

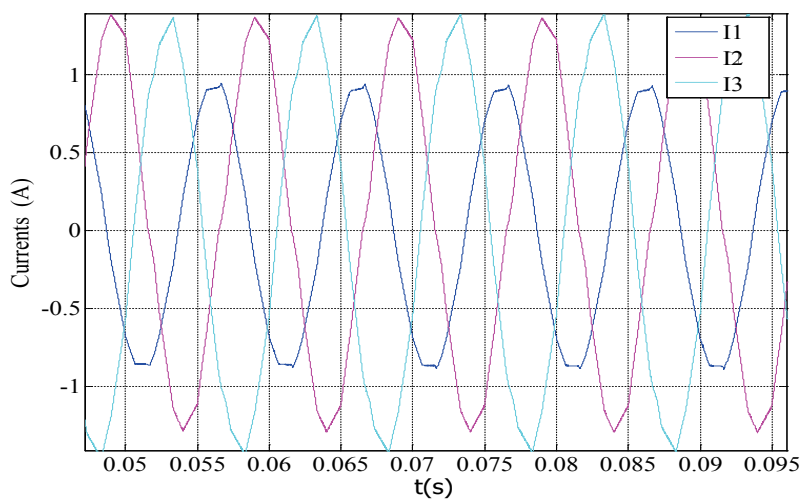

Figure 8 Phase currents of unbalanced $R$ and $L$ loads according to SPWM (common PWM)

Step sinus pulse width modulation controlling inverter drives unbalanced loads, currents of loads which are $I_{c}$, and $I_{b}, I_{c}$ have just sinus shape in Fig. 7 with comparing common sinus pulse width modulation controlling inverter driving unbalanced loads currents as shown in Fig. 8.

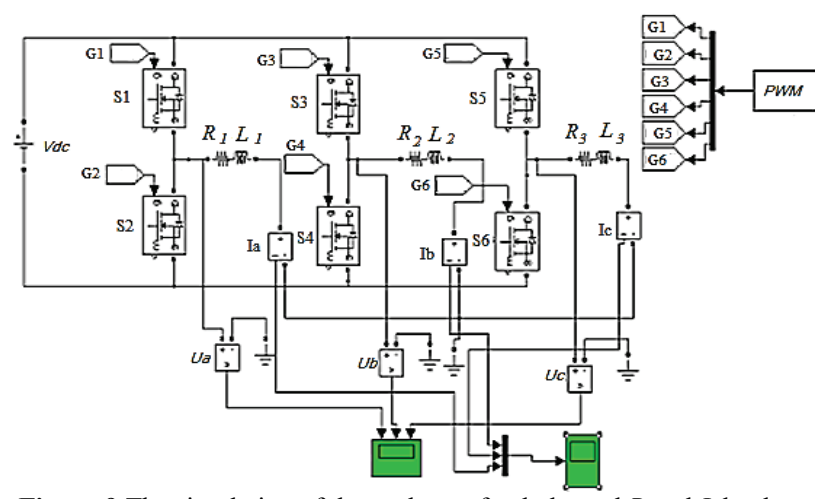

Figure 9 The simulation of three-phase of unbalanced $R$ and $L$ loads at the MATLAB Simulink

While SSPWM controlling inverter provides current shown in Fig. 10, current harmonic distortion is shown in Fig. 11.

$I_{a}$ phase current of harmonic distortion is 1,86\% while shape of $I_{a}$ current is just sinus shape. Inverter producing harmonic distortion is very acceptable for unbalanced loads because produced harmonic is lower than $4 \%$.

While common SPWM controlling inverter provides current shown in Fig. 12, current harmonic distortion is shown in Fig. 13. 


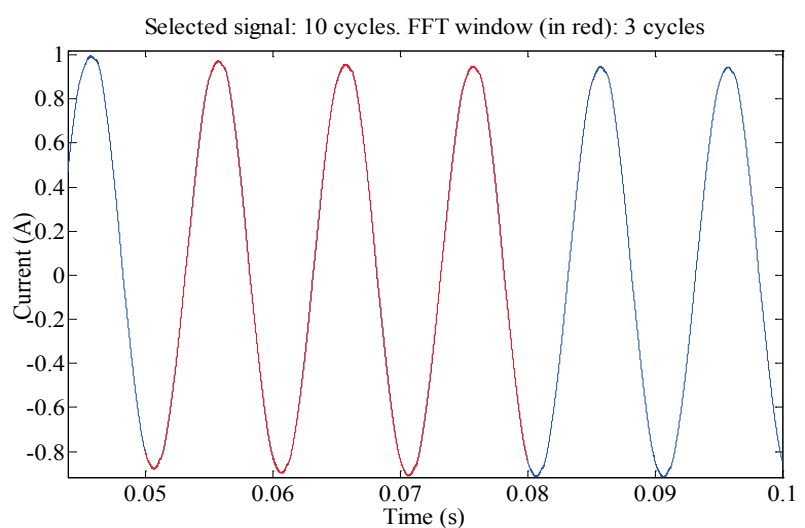

Figure $10 I_{a}$ phase current of unbalanced $R$ and $L$ loads according to SSPWM

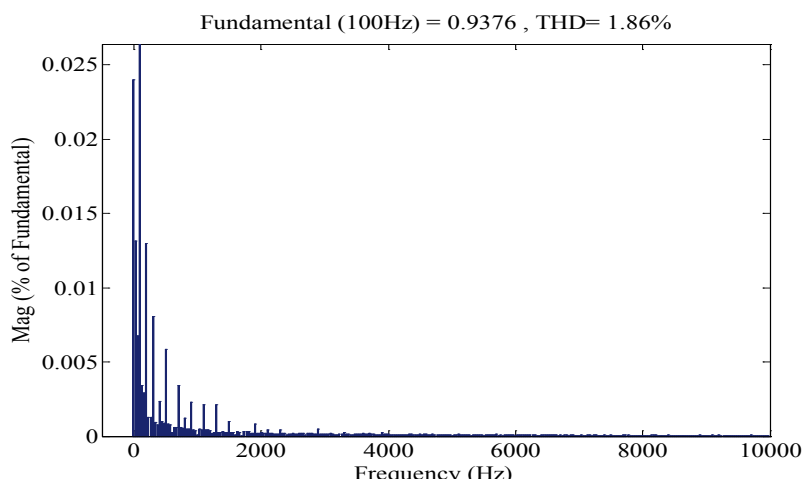

Figure $11 I_{a}$ phase current of harmonic distortion

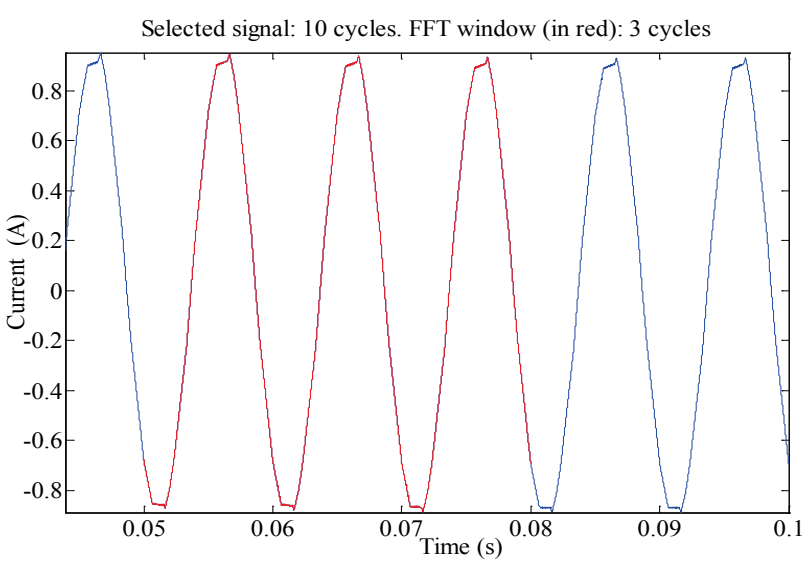

Figure $12 I_{1}$ phase current of unbalanced $R$ and $L$ loads according to common SPWM

Fundamental $(100 \mathrm{~Hz})=0.9198, \mathrm{THD}=2.90 \%$

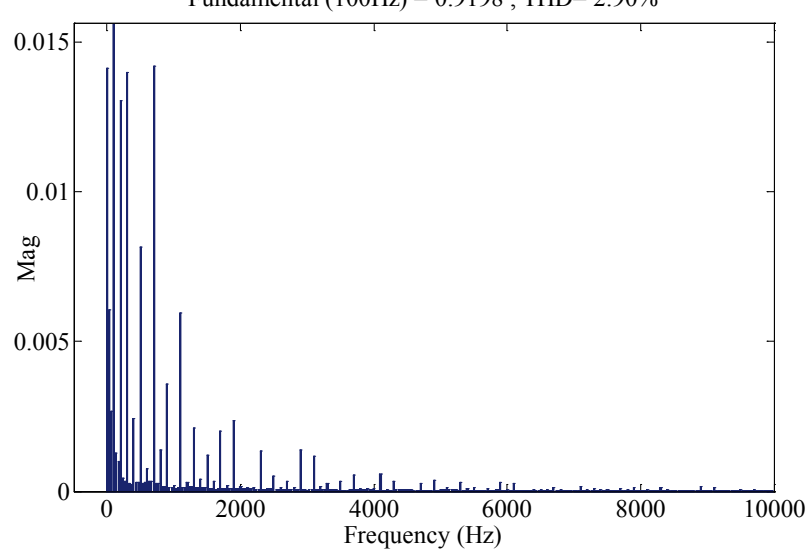

Figure $13 I_{1}$ phase current of harmonic distortion
$I_{a}$ phase current of harmonic distortion is $1,86 \%$ while $I_{1}$ phase current of harmonic distortion is $2,90 \%$. SSPWM inverter producing harmonic distortion is lower than common SPWM Inverter producing harmonic distortion.

\subsection{Inverter implementations}

Resistive and inductive loads are connected to inverter so that step sinus pulse width modulation controlling inverter could compare to common PWM controlling inverter after inverter circuit is constructed. Step sinus pulse width modulation controlling inverter creates alternating voltage that is just sinus shape as shown in Fig. 14. Common pulse width modulation controlling inverter creates alternating voltage sinus following in Fig. 15. Common PWM technique provided alternating voltage has not just sinus shape while the new modulation technique provided alternating voltage has just sinus shape. Therefore new modulation technique is more successful than common PWM techniques which are microchip creating constant PWM or SPWM.

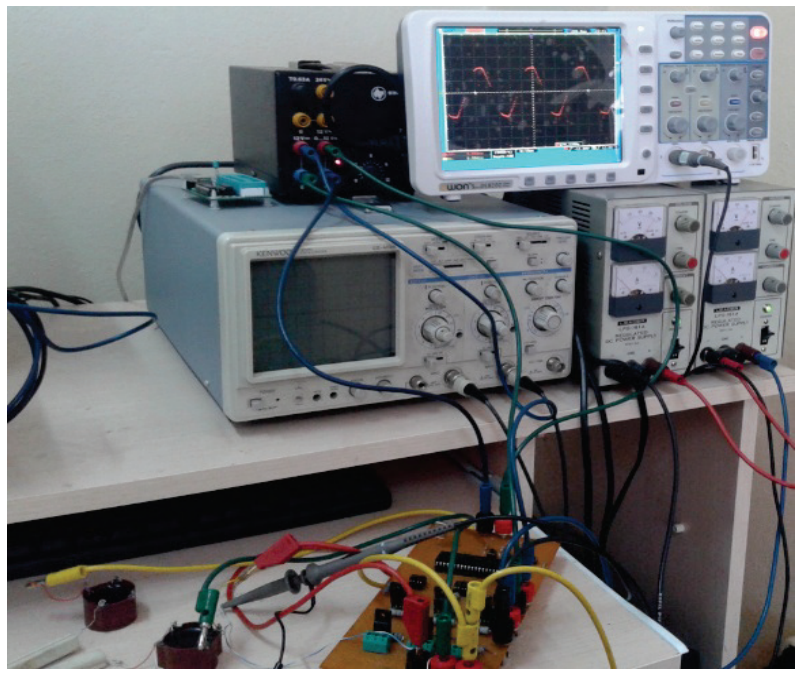

Figure 14 Step sine pulse width modulation controlling inverter load voltage shape

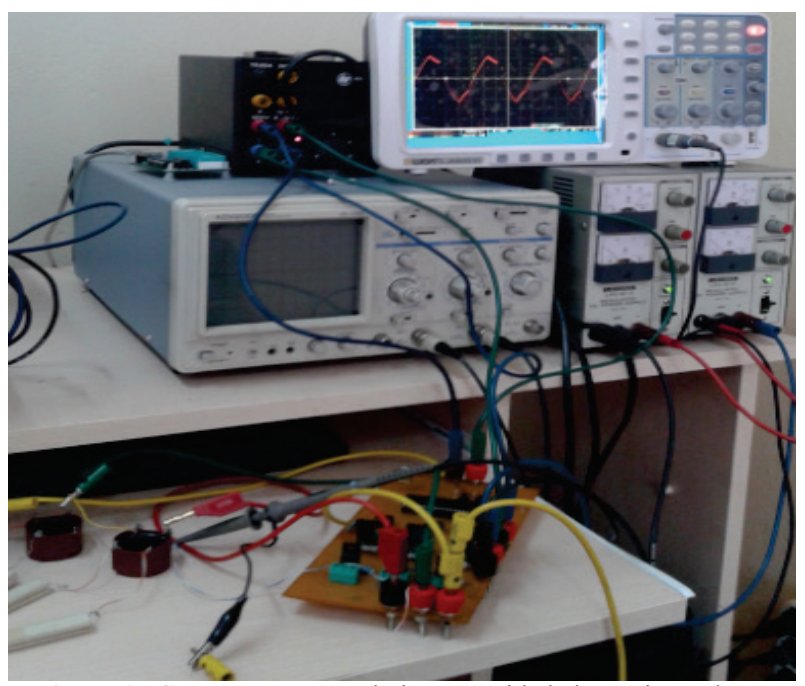

Figure 15 Common PWM technique provided alternating voltage

Appearances of Step sinus pulse width modulation controlling inverter are shown in Fig. 14. Common PWM 
controlling inverter is shown in Fig. 15. The new modulation technique provided alternating voltage is just sinus shape according to Common PWM technique provided alternating voltages sinus shape.

Two phase voltages of SSPWM controlling three phase inverter are shown in Fig. 16 for unbalanced loads becasuse ossiloscope has two channels.

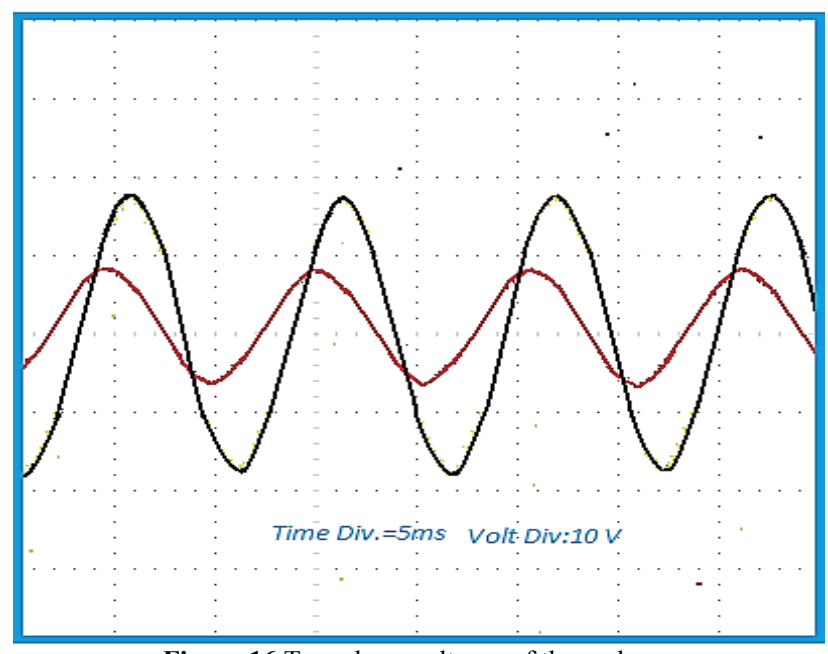

Figure 16 Two phase voltages of three phases

\section{Conclusion}

New mathematical model is performed by the new pulse width modulation technique. Arranged Duty cycles of SSPWM as (5a, 7a, 9a, 11a, and 13a) could provide different mathematical model which are formed as geometrical area calculation and linear mathematical calculation for load voltages. SSPWM controlling the inverter running $R$ and $L$ loads is simulated at the MATLAB Simulink. Simulation results show that SSPWM controlling inverter has demanded level results while common PWM controlling inverter does not demand level results on harmonic distortion. Harmonic distortion for step-sinus pulse width modulation has 1,86 $\%$ while Harmonic distortion for common pulse width modulation has $2,90 \%$. SSPWM inverter producing harmonic distortion is lower than common SPWM inverter producing harmonic distortion and acceptable harmonic distortion which is lower than $4 \%$. After simulations, Microchip 16F877A and MOSFETs are used for inverter circuits in the implementation. Driver circuit is constructed so that power circuit unit could be isolated from the microchip. Therefore, six PC817 transistors are used to construct driver circuit. Inductive and resistive loads are driven in the implementation of the system after simulations. Common PWM technique produced alternating voltage does not have just sinus shapes while the new modulation technique produced alternating voltage has just sinus shape. Results demonstrate new modulation technique and mathematical model provide high performance for unbalanced loads. In addition, Inverter circuit could be constructed at low cost because modulation technique and mathematical model are used on microchip 16F877A which has two outputs of hardware producing PWM. Satisfactory results are obtained in the study.

\section{References}

[1] Baimel, D.; Rabinovici, R.; Tapuchi, S. Hybrid thirteen level cascaded H-bridge inverter. // Electrical Engineering. 98, 3(2016), pp. 207-217. DOI: 10.1007/s00202-015-0356-z

[2] Lee, Kyo-Beum; Blaabjerg, Frede. Performance improvement of sensor less vector control for matrix converter drives using $\mathrm{PQR}$ power theory. // Electrical Engineering. 89, 8(2007), pp. 607-616. DOI: 10.1007/s00202006-0041-3

[3] Can, E.; Sayan, H. H. Different mathematical model for the chopper circuit. // Tehnički glasnik-Technical Journal. 10, 1-2(2016), pp. 13-15.

[4] Can, E. Novel High Multilevel Inverters Investigated on Simulation. // Electrical Engineering. (2016), DOI: 10.1007/s00202-016-0396-z

[5] Kömürcügil, H. Integral sliding-mode-based currentcontrol strategy for single-phase current-source inverters. // Electrical Engineering. 93, 3(2011), pp. 127-136. DOI: 10.1007/s00202-011-0197-3

[6] $\mathrm{Su}, \mathrm{G}$. J. Pulse-Width-Modulation Schemes for an Integrated Traction and Compressor Drive System. // $21^{\text {st }}$ Applied Power Electronics Conference and Exposition (APEC'06), vol. 2, March 19-23, 2006, pp. 640-645. DOI: 10.1109/apec.2006.1620606

[7] Salazar, L.; Joos, G. PSPICE simulation of three-phase inverters by means of switching functions. // IEEE Trans Power Electron. 9, (1994), pp. 35-42. DOI: 10.1109/63.285491

[8] Elmas C.; Deperlioglu, O.; Sayan, H. H. Adaptive fuzzy logic controller for DC converters. // Expert Systems with Applications. 36, (2009), pp. 1540-1548. DOI: 10.1016/j.eswa.2007.11.029

[9] Kouki, H.; Fredj, M. B.; Rehaoulia, H. Harmonic analysis of SVPWM control strategy on VSI-fed double-star induction machine performances. // Electrical Engineering. 98, 2(2016), pp. 133-143. DOI: 10.1007/s00202-015-0358-x

[10] Can, E.; Sayan, H. H. PID and fuzzy controlling three phase asynchronous machine by low level DC source three phase inverter. // Tehnički vjesnik-Technical Gazette. 23, 3(2016), pp. 753-760. DOI: 10.17559/TV-20150106105608

[11] Xiao, Zhenfeng; Yuan, Rongxiang; Chen, Yilong; Chen, Qijuan; Deng, Xiangtian. Active Power Filter Control Strategy with Novel Dual-Repetitive Controller and Neural Network Adaptive PI Control. // Tehnicki vjesnikTechnical Gazette. 21, 3(2014), pp. 545-551.

[12] Ertay, M. M.; Zengin, A. Analysis of the discontinuous PWM controlled D-STATCOM for reactive power compensation applications. // Tehnicki vjesnik-Technical Gazette. 21, 4(2014), pp. 825-833.

\section{Authors' addresses}

Asst. prof. dr. Erol Can

Department of Aircraft Airframe Powerplants, School of Civil Aviation, Erzincan University, Erzincan, Turkey

E-mail: can_e@hotmail.com

\section{Asst. prof. dr. H. Hüseyin Sayan}

Gazi University, Faculty of Technology, Department of Electrical and Electronics Engineering, Ankara, Turkey

E-mail: hsayan@gazi.edu.tr 